\title{
HYDRODYNAMICS AND SUSPENDED SEDIMENT TRANSPORT IN THE CAMBORIÚ ESTUARY - BRAZIL: PRE JETTY CONDITIONS
}

\author{
Eduardo Siegle ${ }^{1}$; Carlos A. F. Schettini ${ }^{2}$; Antonio H. F. Klein ${ }^{3}$ and Elírio E. Toldo Jr. ${ }^{4}$ \\ ${ }^{1}$ Instituto Oceanográfico da Universidade de São Paulo \\ (Praça do Oceanográfico, 191, 05508-120 São Paulo, SP, Brasil) \\ esiegle@io.usp.br \\ ${ }^{2}$ Universidade Federal do Ceará - Instituto de Ciências do Mar - LABOMAR \\ (Av. da Abolição, 3207, 60165-081 Fortaleza, CE, Brasil) \\ ${ }^{3}$ Universidade do Vale do Itajaí - Centro de Ciências Tecnológicas da Terra e do Mar \\ (Rua Uruguai, 458, 88302-202 Itajaí, SC, Brasil)
}

${ }^{4}$ Universidade Federal do Rio Grande do Sul - Centro de Estudos de Geologia Costeira e Oceânica (Caixa Postal 15001, 91509-900 Porto Alegre, RS, Brasil)

\begin{abstract}
A B S TR ACT
Estuarine hydrodynamics is a key factor in the definition of the filtering capacity of an estuary and results from the interaction of the processes that control the inlet morphodynamics and those that are acting in the mixing of the water in the estuary. The hydrodynamics and suspended sediment transport in the Camboriú estuary were assessed by two field campaigns conducted in 1998 that covered both neap and spring tide conditions. The period measured represents the estuarine hydrodynamics and sediment transport prior to the construction of the jetty in 2003 and provides important background information for the Camboriú estuary. Each field campaign covered two complete tidal cycles with hourly measurements of currents, salinity, suspended sediment concentration and water level. Results show that the Camboriú estuary is partially mixed with the vertical structure varying as a function of the tidal range and tidal phase. The dynamic estuarine structure can be balanced between the stabilizing effects generated by the vertical density gradient, which produces buoyancy and stratification flows, and the turbulent effects generated by the vertical velocity gradient that generates vertical mixing. The main sediment source for the water column are the bottom sediments, periodically resuspended by the tidal currents. The advective salt and suspended sediment transport was different between neap and spring tides, being more complex at spring tide. The river discharge term was important under both tidal conditions. The tidal correlation term was also important, being dominant in the suspended sediment transport during the spring tide. The gravitational circulation and Stokes drift played a secondary role in the estuarine transport processes.
\end{abstract}

\section{RESUMO}

As trocas de água e materiais através das desembocaduras de estuários são de difícil quantificação e são de fundamental importância para o entendimento do funcionamento de estuários e da zona costeira. A hidrodinâmica e transporte de sedimentos em suspensão no estuário do rio Camboriú foram estudados através da realização de duas campanhas de campo em 1998 cobrindo as condições de quadratura e sizígia. O período do levantamento foi anterior à obra de construção do molhe em 2003 que alterou a morfologia da desembocadura, fornecendo assim importantes informações base sobre o sistema. Cada experimento cobriu dois ciclos de maré com medições horárias de correntes, salinidade, concentrações de sedimentos em suspensão e nível de água. Os resultados mostram que o estuário é parcialmente misturado com estrutura vertical variando em função da amplitude e fase da maré. A estrutura dinâmica do estuário é balanceada entre os efeitos estabilizadores gerados pelo gradiente vertical de densidade, que permite produzir fluxo de empuxo e estratificação, e os efeitos turbulentos gerados pelo gradiente vertical de velocidade, que gera mistura vertical. A principal fonte de sedimentos para a coluna de água são os sedimentos de fundo, periodicamente resuspendidos pelas correntes de maré. O transporte advectivo de sal e sedimentos em suspensão foi diferente entre condições de quadratura e sizígia, sendo mais complexo durante a sizígia. A circulação gravitacional e a deriva de Stokes apresentam um papel secundário nos processos de transporte estuarinos.

Descriptors: Suspended sediment transport, Salt transport, Estuarine hydrodynamics, Camboriú estuary.

Descritores: Transporte de sedimentos em suspensão, Transporte de sal, Hidrodinâmica estuarina, Estuário do rio Camboriú.

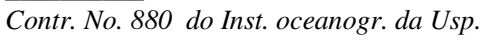




\section{INTRODUCTION}

The quantification of water and other materials through estuarine mouths is not a simple task, it is, however, fundamental to the comprehension of the functioning of estuaries and coastal seas (DYER et al., 1992). Estuaries act as filters to dissolved and particulate materials originated in the drainage basin and carried down to the sea by streams (e.g. SHUBEL; CARTER, 1984). Nevertheless, the filtering efficiency of a particular estuary is a complex function and difficult to estimate. Estuarine hydrodynamics is a key factor, and it is the result of the interaction of processes that control the inlet morphodynamics (waves, tides, fluvial discharge and sediment supply) and those that act in the mixing of the water in the estuary. Dyer (1995) presents a conceptual model in which the filtering efficiency is a function of the predominant estuarine circulation. Highly stratified estuaries present smaller filtering efficiency, since fluvial advection is the main transport process; partially mixed estuaries present higher filtering efficiency, also being traps for coastal sediment, processes related to the importance of the gravitational circulation in these estuaries; well mixed estuaries will present more complex patterns, since the interactions between harmonic tidal constituents, friction and morphology will produce current asymmetries that cause either low or high filtering efficiency.

Suspended sediments in estuaries and coastal waters are mainly in flocculated state of clay mineral particles and organic matter (EISMA, 1986), being particularly important to the sedimentary and biogeochemical cycles, as flocs are highly sensitive to hydrodynamics and act as adsorption surfaces to dissolved materials, including pollutants (FÖRSTNER;WITTMANN, 1983). The knowledge of the dynamics of fine sediment dynamics can be used as a good approximation to the dynamics of pollutants in estuaries and coastal seas (DYER, 1997). Suspended sediments can be retained temporarily in the maximum turbidity zone or settled in intertidal areas. Settling, erosion and transport processes are not coupled with dissolved material fluxes during the oscillatory tidal regime. Lag effects between tidal currents and suspended sediment concentration can produce residual transport of sediments even with no residual water transport, although with some order of current asymmetry (DYER, 1997). The total mass transport in estuaries, whether of particulate or dissolved materials, can be interpreted by the decomposition of the advective transport mechanisms, physically related to natural phenomena such as river advection, tidal dispersion, Stokes drift, tidal shear, gravitational circulation and residual effects (DYER, 1978; KJERFVE, 1986).
Although it is small, the Camboriú estuary (Fig. 1) is very important in ecological, social and economic terms. The Balneário Camboriú city is the largest coastal resort in southern Brazil, attracting a large number of tourists. It is thus of great economic importance and environmental quality is of strategic significance. The first study of the hydrodynamic characteristics of the Camboriú estuary was presented by Schettini et al. (1996); in it they classified the estuary as partially stratified based on a 13-hour neap tide field survey. Pereira et al. (2001) assessed the dissolved nutrient fluxes and the bay-estuary interaction, based on a 25-hour spring tide survey. These authors observed that there is a detritus belt that enters and exits the estuary periodically with tide, suggesting a low flushing rate even during spring tides. Franklin-Silva and Schettini (2003) assessed the lateral hydrodynamic structure and advective salt transport mechanisms of the estuary based on two field surveys, for neap and spring tides. Their findings show that the estuary is laterally homogenous in terms of salinity and that the salt transport is controlled by a sinodical modulation. Under neap tide conditions, the main transport mechanisms are related to the tide and entering the estuary, while during spring tides the main transport mechanism is related to fluvial advection and leaving the estuary. The objective of this study is to better understand the hydrodynamics of the Camboriú estuary, with a focus on the suspended sediment dynamics, based on two field surveys covering two neap and two spring tidal cycles. The field experiments were conducted before the construction of the jetty at the mouth of the estuary, thus providing important background information on the region.

\section{Methods}

Field Experiments

Two field experiments were conducted covering neap (6-7 February 1998) and spring (12-13 March 1998) tide conditions. Each campaign covered two complete tidal cycles (25 hours) measuring vertical profiles of current intensity and direction, salinity, temperature, suspended sediment concentration and water level. The data were collected in the middle of the estuary channel close to its inlet (Fig. 1) in the middle of the channel cross-section (Fig. 2). Flow velocity and direction were measured with three SensorData SD6000 current meters moored so as to measure flow at $0.5 \mathrm{~m}$ and $1 \mathrm{~m}$ above the bed and at $0.5 \mathrm{~m}$ below the surface. These three current meters gathered data at $5 \mathrm{~min}$. intervals during the 25 hours of each experiment. Close to the current meters' moorings, hourly vertical profiles were carried out to 
measure salinity, temperature and suspended sediment concentrations. Salinity and temperature were recorded at the vertical section with a MiniSTD SensorData SD201. Suspended sediment concentrations were recorded with an optical backscattering nephelometer at $0.5 \mathrm{~m}$ intervals in the water column. The nephelometer had been previously calibrated to measure concentrations of up to $300 \mathrm{mg} \cdot \mathrm{l}^{-1}$. Surface elevation was monitored at two points, one close to the monitored cross-section and the other at the upper limit of the estuary, defined by the presence of a small dam. These water level measurements allowed the estimation of the estuarine tidal prism. The cross-sectional area was calculated based on an echo-sounding survey carried out during the first field experiment. Soundings are corrected to the Brazilian Institute of Geography and Statistics (IBGE) zero level. For the suspended sediment and water flux calculations, the cross-sectional area has been considered as a function of time, thereby including its changes due to water level oscillations.

\section{Data Processing}

Flow velocity and direction have been reduced to the main channel axis in order to eliminate the transversal circulation effects. The salinity and suspended sediment concentration data have been reduced to the surface, middle, and bottom levels through 'spline' interpolation in MATLAB. Positive values mean inflow (landward) and negative values mean estuarine outflow (seaward). The vertical/temporal diagrams of the distribution of the variables measured have been plotted with the Surfer software (Golden Software Inc.) using the linear kriging interpolation method.
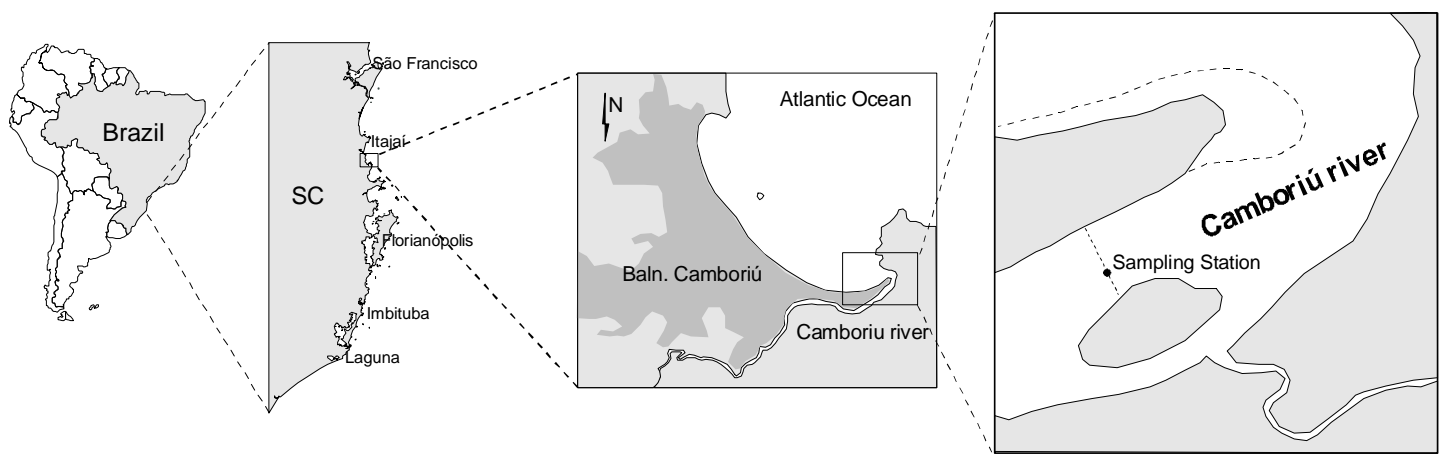

Fig. 1. Location of the study area, showing the position of the sampling station.

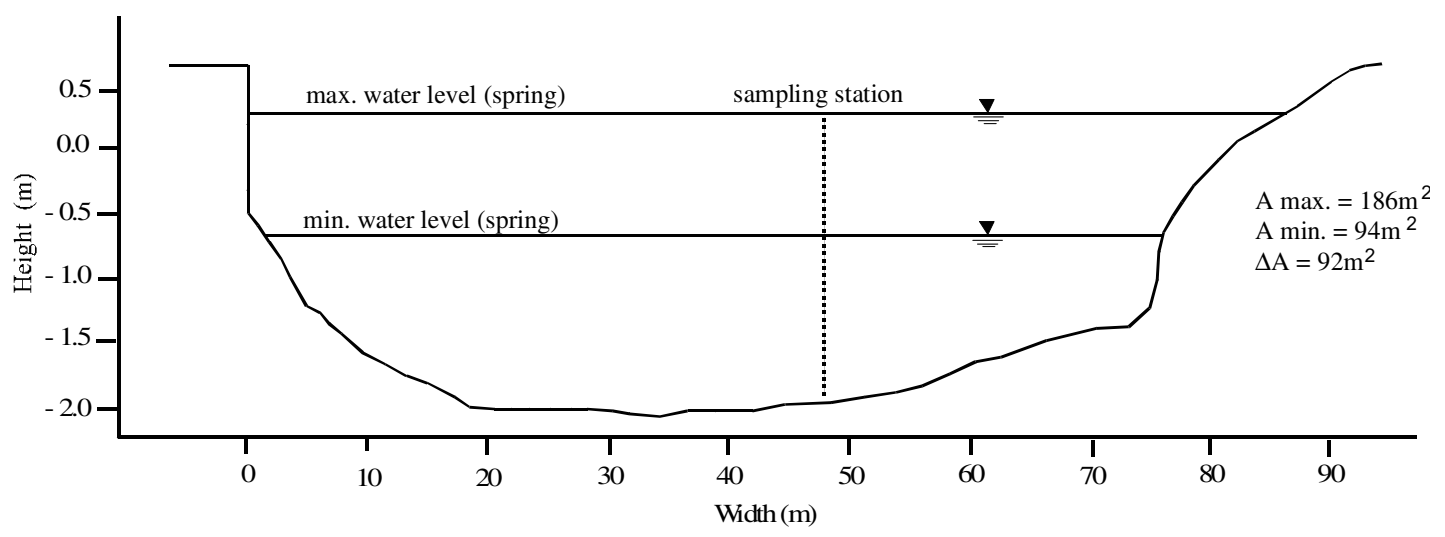

Fig. 2. Channel cross-section at the data collection station (levels relate to the IBGE datum, $A=$ area). 
The instant water flow $Q_{t}\left(\mathrm{~m}^{3} \cdot \mathrm{s}^{-1}\right)$ has been calculated for each hour by

$Q_{t}=\bar{u} \cdot A_{t}$

where $\bar{u}\left(\mathrm{~m} \cdot \mathrm{s}^{-1}\right)$ is the mean velocity perpendicular to the cross-section and $A_{t}\left(\mathrm{~m}^{2}\right)$ is the cross-sectional area, both taken at time $t$. Similarly, the suspended sediment transport $F_{t}\left(\mathrm{~kg} . \mathrm{s}^{-1}\right)$ is estimated by

$$
F_{t}=10^{-3} \cdot Q_{t} \cdot C_{t}
$$

where $C_{t}\left(\mathrm{mg} . \mathrm{l}^{-1}\right)$ is the suspended sediment concentration in time $t$. These estimates do not take the variation in the parameters along the cross-section into consideration, and these may be important in some estuaries and lead to errors in the flux estimates (Boon, 1977). However, Franklin-Silva and Schettini (2003) showed that the Camboriú estuary is laterally homogeneous in terms of salinity. Considering that this homogeneity reflects the estuarine hydrodynamics, the flux estimates using measurements taken in the middle of the channel can be considered as a good approximation for this system.

Advective Salt and Suspended Sediment Transport Decomposition

In order to evaluate the relative importance of the processes involved in the salt and suspended sediment transport, we applied a procedure to decompose the advective transport. The method used is that described by Miranda et al. (2002), which is based on the earlier work of Bowden (1963), Fisher (1976), Hunkins (1981), Dyer (1974) and Kjerfve (1986). The decomposition assumes a laterally homogeneous cross-section, as is the case of the lower Camboriú estuary (FRANKLIN-SILVA; SCHETTINI, 2003). The instantaneous longitudinal velocity at a given time, at a given distance from the inlet and at a given depth can be decomposed as the sum of the fluvial, barotropic and baroclinic advection and a residue, in the form $u(x, z, t)=u_{a}(x)+u_{t}(x, t)+u_{s}(x, z)+u^{\prime}(x, z, t)$

The fluvial advection component $\left(u_{a}\right)$ is obtained by the vertically and temporally averaged flow for one or more tidal cycles $(<\bar{u}\rangle)$. The barotropic component, $u_{t}$, represents the mean flow velocity variation through one or more tidal cycles, without the fluvial advection:

$u_{t}(t)=\bar{u}(t)-<\bar{u}>$

and the baroclinic component, $u_{s}$, represents the mean flow velocity for each measured level, without the fluvial advection:

$u_{s}(z)=<u(z)>-<\bar{u}>$

and the residue is obtained by isolating the last term on the right side of equation 3. The same decomposition can be applied for salinity and for the SSC. The depth at the sampling point, $h$, also varies during the tidal cycle, and can be decomposed in terms of the instantaneous level variation, $h_{t}$, related to the mean depth $h_{a}$ :

$h(x, t)=h_{a}(x)+h_{t}(x, t)$

The total salt transport, $T_{s}$, averaged for a tidal cycle and for each meter of the cross-section is given by:

$T_{s}=\frac{1}{T} \int_{0}^{T} \int_{0}^{h} \rho u S d z d t$

where $\rho$ is the water density and $S$ the salinity. By replacing the integral parameters $u$ and $S$ by the equation 3 and its analogous for salinity, we get 32 terms, from which only seven terms present physical significance and are other than zero. The total salt transport during a tidal cycle may thus be rewritten as:

$$
\left.\begin{array}{c}
i \\
T_{s}=\bar{\rho}\left(u_{a} h_{a} S_{a}+S_{a}<u_{t} h_{t}>+h_{a}<u_{t} S_{t}>+h_{a} \overline{u_{s} S_{s}}\right.
\end{array}+h_{a}<\overline{u^{\prime} S^{\prime}}>+<u_{t} h_{t} S_{t}>+u_{a}<S_{t} h_{t}>\right)
$$


The suspended sediment transport may be written similarly, excluding the density and using concentration in the same metric units as the flow velocity. The physical interpretation of the terms on the right side of the equation can be related to: i: river discharge; ii: Stokes drift; iii: tidal correlation; iv: gravitational circulation; v: shear and random events; vi: tide dispersion; and vii: residual transport (MIRANDA et al., 2002).

\section{RESUlts}

The results of both neap and spring surveys are shown in Figures 3 and 4. The water level, flow velocity, salinity, SSC, water and sediment flux and the ratio between SSC close to the bottom $\left(C_{B}\right)$ and mean SSC in the water column $(\bar{C})$ time series are given, representing the measured and calculated parameters for each condition surveyed. The water surface elevation is represented at the top of the flow velocity, salinity and SSC time series. Table 1 presents a summary of the results for each campaign.

Tidal attenuation creates a gradient between the inlet and the upper estuary limit of $0.3 \mathrm{~m}$ (tidal range of $0.8 \mathrm{~m}$ at the inlet and $0.5 \mathrm{~m}$ at the upper limit) during the neap tide and of only $0.06 \mathrm{~m}$ (tidal range of $1.2 \mathrm{~m}$ at the inlet and $1.14 \mathrm{~m}$ at the upper limit) during the spring tide. Based on these values and the estuary area, the tidal prism has been estimated as being of about $2.6 \times 10^{5} \mathrm{~m}^{3}$ and $4.4 \times 10^{5} \mathrm{~m}^{3}$ for neap and spring tides, respectively.

A

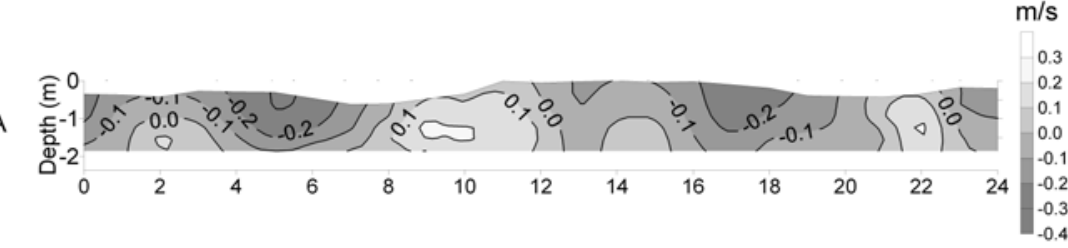

B

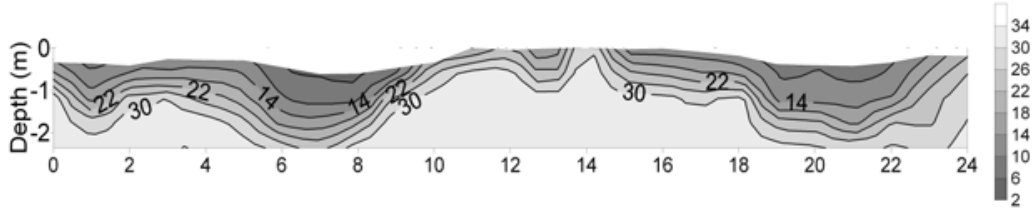

C
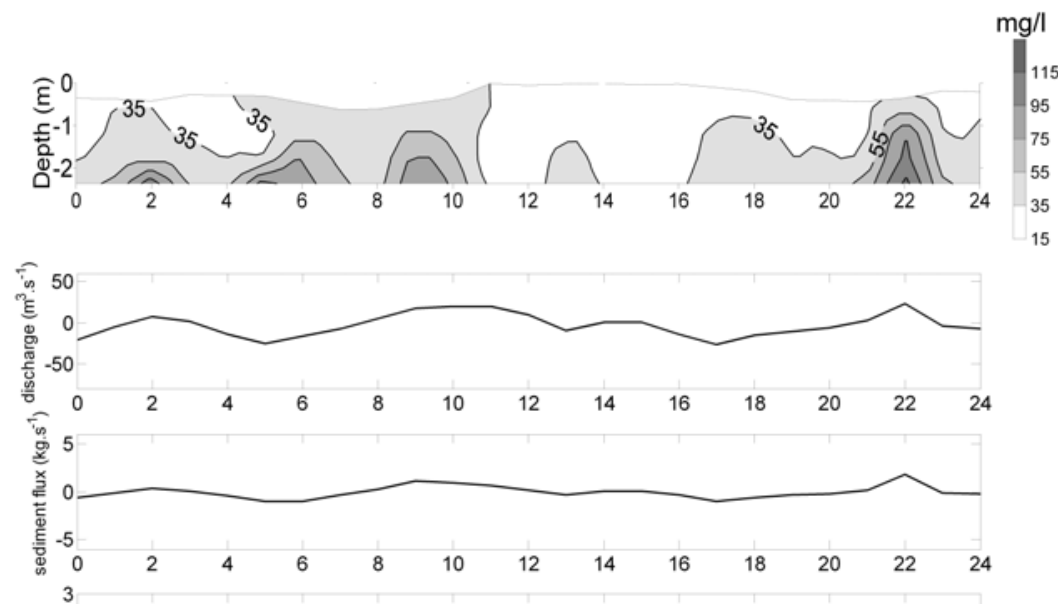

$\mathrm{F}$

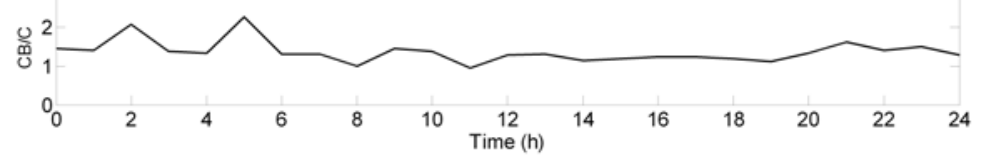

Fig. 3. Distribution of the flow velocities (A), salinity (B), suspended sediment concentration (C), and time dependent water discharge (D), suspended sediment transport (E) and the ratio $C_{B} / \bar{C}$ (F) for the two neap tidal cycles surveyed. Negative values: seaward; positive values: landward. 
A
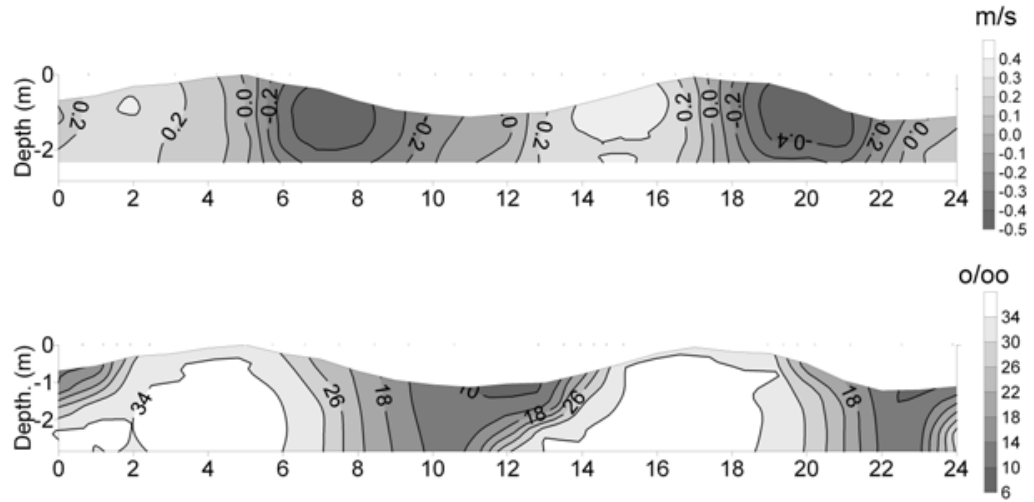

C

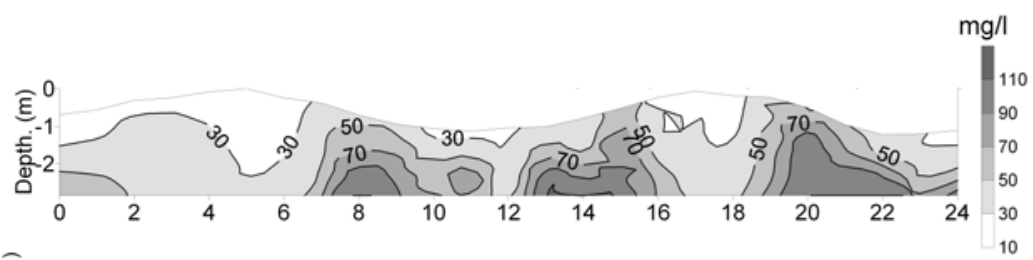

D

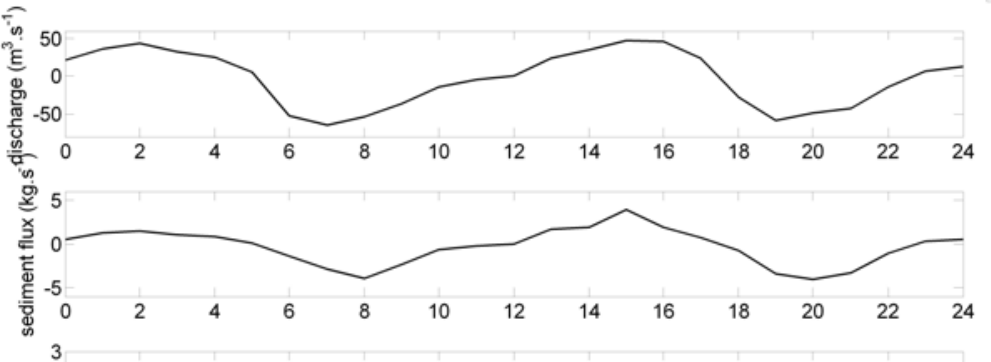

$\mathrm{F}$

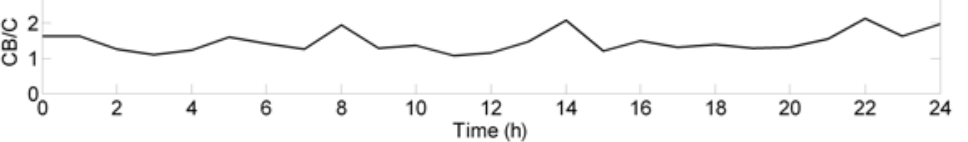

Fig. 4. Distribution of the flow velocities (A), salinity (B), suspended sediment concentration (C), and time dependent water discharge (D), suspended sediment transport (E) and the ratio $C_{B} / \bar{C}$ (F) for the two spring tidal cycles surveyed. Negative values: seaward; positive values: landward.

Table 1. Summary of results for each condition surveyed.

\begin{tabular}{ccc}
\hline \hline & Neap & Spring \\
\hline Tidal range $(\mathrm{m})$ & 0.8 & 1.2 \\
Max. ebb flow $\left(\mathrm{m} . \mathrm{s}^{-1}\right)$ & 0.35 & 0.60 \\
Max. flood flow & 0.25 & 0.40 \\
$\left(\mathrm{~m} . \mathrm{s}^{-1}\right)$ & & \\
Min. salinity & 6 & 8 \\
Max. salinity & 33 & 34 \\
Min. SSC & 15 & 10 \\
Max. SSC & 120 & 120 \\
\hline
\end{tabular}


The cross-sectional area at the sampling station varied from 94 to $157 \mathrm{~m}^{2}$ during neap and from 94 to $186 \mathrm{~m}^{2}$ during spring tide, resulting in variations of $40 \%$ and $50 \%$ during the tidal oscillations.

During the periods surveyed, ebb flows were dominant. Neap peak flow velocities reached $0.25 \mathrm{~m} . \mathrm{s}^{-1}$ during flood and $0.35 \mathrm{~m} \cdot \mathrm{s}^{-1}$ during ebb tide, a $15 \%$ difference. The difference was greater during spring tide, with ebb flows being $36 \%$ higher. The peak flow velocities were of 0.40 and $0.60 \mathrm{~m} . \mathrm{s}^{-1}$ for flood and ebb, respectively. Different patterns of salinity distribution can be seen during neap and spring tides. During neap tide the water column presented an almost permanent stratification, with salinity varying from 2 to 35 (Fig. 3B). During spring tide, the water column is homogenous most of the time, except at the beginning of the flood tide, when increased stratification is observed. Salinity varied from 6 to 35 under these conditions (Fig. 4B). The SSC varied from 10 to $120 \mathrm{mg} . \mathrm{l}^{-1}$ during both studied tide conditions, always with highest concentrations near the bottom and in phase with the peak flood and ebb velocities (Figs 3C and 4C). Figure 5 shows the time averaged results for both conditions. The instantaneous water flux $\left(Q_{t}\right)$ varied between -26 and $23 \mathrm{~m}^{3} \cdot \mathrm{s}^{-1}$ during the neap tide and between -64 and $47 \mathrm{~m}^{3} \cdot \mathrm{s}^{-1}$ during the spring tide (Figs 3.3D and 3.4D). The suspended sediment flux estimated for each crosssectional unit is -0.001 and $-0.005 \mathrm{~kg} \cdot \mathrm{m}^{-1} \cdot \mathrm{s}^{-1}$, respectively, for neap and spring conditions. Instantaneous suspended sediment fluxes are presented in Figures 3E and 4E.

The suspended sediment transport, calculated with equation 2 , was of $3,450 \mathrm{~kg} /$ tidal cycle and $16,200 \mathrm{~kg} /$ tidal cycle for neap and spring tide, respectively. Under both conditions the net transport was seaward. The decomposed salt and suspended sediment fluxes by cross-sectional unit, obtained with equation 8 , are presented in Table 2. The most important terms controlling the salt transport during neap tide are the river discharge $\left(-1.13 \mathrm{~kg} \cdot \mathrm{s}^{-1} \cdot \mathrm{m}^{-1}\right)$, tidal correlation $\left(0.19 \mathrm{~kg} \cdot \mathrm{s}^{-1} \cdot \mathrm{m}^{-1}\right)$ and the gravitational circulation $\left(0.66 \mathrm{~kg} \cdot \mathrm{s}^{-1} \cdot \mathrm{m}^{-1}\right)$. During spring tide, the same terms added to the Stokes drift are the most important in controlling salt transport, with river discharge of $-1.19 \mathrm{~kg} \cdot \mathrm{s}^{-1} \cdot \mathrm{m}^{-1}$; tidal correlation of $1.18 \mathrm{~kg} \cdot \mathrm{s}^{-1} \cdot \mathrm{m}^{-1} ; \quad$ gravitational circulation of $0.12 \mathrm{~kg} . \mathrm{s}^{-1} \cdot \mathrm{m}^{-1}$; and Stokes drift of $0.20 \mathrm{~kg} \cdot \mathrm{s}^{-1} \cdot \mathrm{m}^{-1}$. The advective transport of SSC during neap tide has been balanced between the river discharge and tidal correlation terms, with values of $-1.89 \times 10^{-6}$ and 1.40 $\mathrm{x} 10^{-6} \mathrm{~kg} \cdot \mathrm{s}^{-1} \cdot \mathrm{m}^{-1}$, respectively. During spring tide, four terms are the most important in determining the advective salt transport, these being river discharge $\left(2.31 \times 10^{-6} \mathrm{~kg} \cdot \mathrm{s}^{-1} \cdot \mathrm{m}^{-1}\right)$, Stokes drift $\left(0.40 \times 10^{-6}\right.$ $\left.\mathrm{kg} \cdot \mathrm{s}^{-1} \cdot \mathrm{m}^{-1}\right)$, tidal correlation $\left(-3.94 \times 10^{-6} \mathrm{~kg} \cdot \mathrm{s}^{-1} \cdot \mathrm{m}^{-1}\right)$ and the gravitational circulation $\left(0.62 \times 10^{-6}\right.$ $\left.\mathrm{kg} \cdot \mathrm{s}^{-1} \cdot \mathrm{m}^{-1}\right)$.
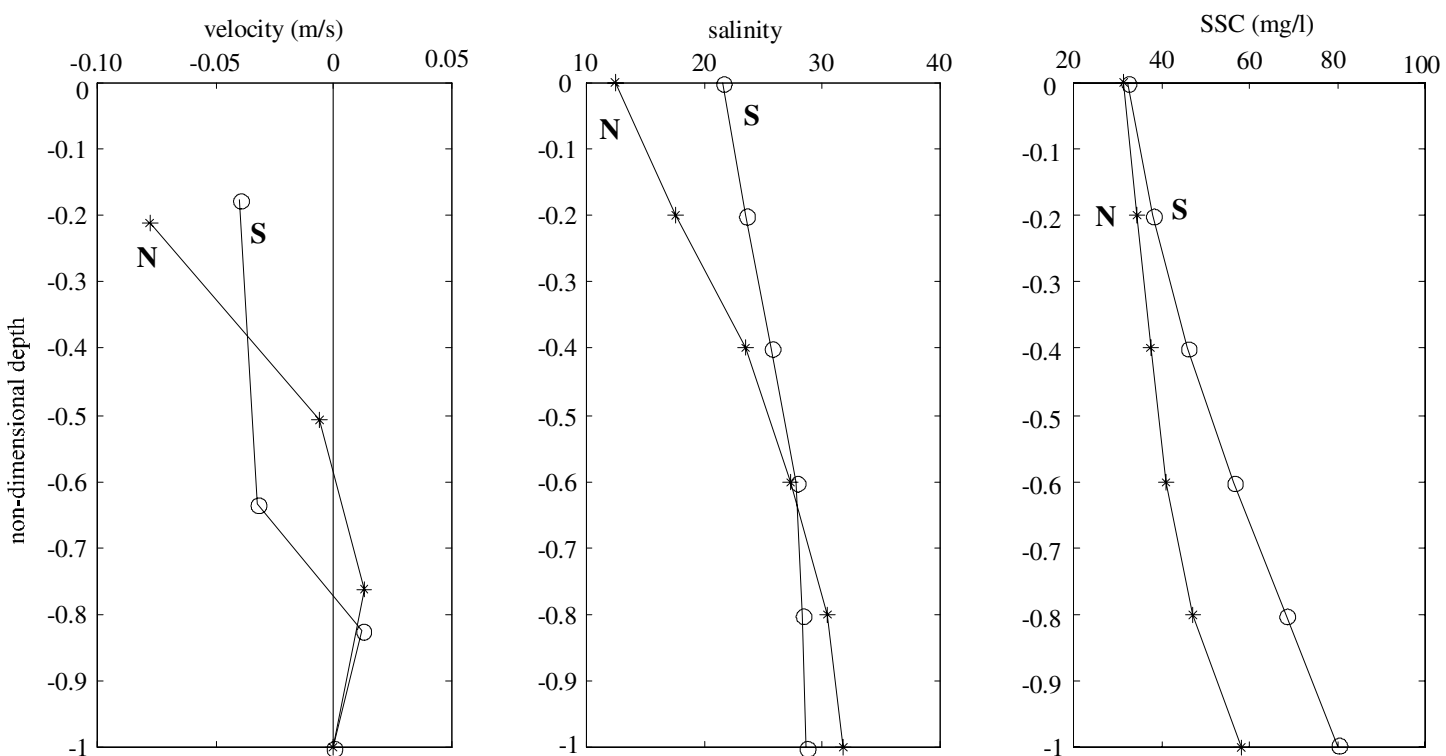

Fig. 5. Vertically averaged profiles of current velocities, salinity and suspended sediment concentration (SSC) measured at the data collection station. Neap tide results are represented by $\mathbf{N}$ and spring tide results by $\mathbf{S}$. 
Table 2. Salt $\left(\mathrm{kg} \cdot \mathrm{s}^{-1} \cdot \mathrm{m}^{-1}\right)$ and suspended sediment fluxes $\left(\mathrm{kg} \cdot \mathrm{m}^{-1} \cdot \mathrm{s}^{-1} \mathrm{x} 10^{-6}\right)$ in the Camboriú estuary.

\begin{tabular}{ccccc}
\hline \hline \multicolumn{2}{c}{} & Neap & & \multicolumn{2}{c}{ Spring } \\
\hline Salt & Sediment & Salt & Sediment \\
River discharge & $\mathbf{- 1 . 1 3}$ & $\mathbf{- 1 . 8 9}$ & $\mathbf{- 1 . 1 9}$ & $\mathbf{- 2 . 3 1}$ \\
Stokes drift & -0.04 & -0.08 & $\mathbf{0 . 2 0}$ & $\mathbf{0 . 4 0}$ \\
Tidal correlation & $\mathbf{0 . 1 9}$ & $\mathbf{1 . 4 0}$ & $\mathbf{1 . 1 8}$ & $\mathbf{- 3 . 9 4}$ \\
Gravitational & $\mathbf{0 . 6 6}$ & 0.04 & $\mathbf{0 . 1 2}$ & $\mathbf{0 . 6 2}$ \\
Circulation & & & 0.01 & 0.03 \\
Shear & 0.05 & 0.02 & -0.01 & 0.06 \\
Tidal dispersion & 0.00 & -0.08 & -0.06 & 0.06 \\
Residual transport & -0.02 & 0.03 & 0.25 & -5.08 \\
Total transport & -0.29 & -0.24 & & \\
\hline
\end{tabular}

Both surveyed periods were preceded by similar rain conditions. Precipitation data collected at the Itajaí meteorological station (at approx. $15 \mathrm{~km}$ from the Camboriú estuary - linked to the CLIMERH/EPAGRI) were of 262.5 and $255.5 \mathrm{~mm}$ during the 30 days that preceded the neap and spring tide surveys, respectively.

\section{DisCUSSION \\ Hydrodynamics}

Different patterns of current velocities have been found during neap and spring tides, according to the tidal oscillation for each condition. During the neap tide, the relation between water level and flow velocities is not always clear. The main reason for this dissociation is probably the presence of the shallow water quarti-diurnal components of the tidal harmonic constants. These constituents are generated during the tidal wave propagation over the continental shelf, being the energy transfer from pure astronomic constituents to shallow water constituents directly related to the shelf width (PUGH, 1987). During first and last quarter moon, when the semi-diurnal constituents are not in phase with the diurnal constituents, the shallow water constituents become more important in the water level and current modulation, inducing velocity oscillations of lower frequencies than those of the semi-diurnal cycles, resulting in higher intra-tidal variability. On the other hand, this is not observed during spring tide, since the diurnal and semi-diurnal constituents are in phase, overcoming the lower frequency oscillations, allowing the currents to follow the water level oscillation pattern. Schettini (2002) shows that for the Itajaí-Açú estuary (at around $20 \mathrm{~km}$ to the north of the Camboriú estuary), the quarti-diurnal and the diurnal constituents have equivalent importance in the tidal modulation.
Given the proximity of both systems, the same probably happens in the Camboriú estuary.

The vertical structure of the Camboriú estuary varied as a function of the tidal range and tidal phase. The estuarine dynamic structure can be balanced between the stabilizing effects generated by the vertical density gradient, which produces buoyancy and stratification flows, and the turbulent effects generated by the vertical velocity gradient that generates vertical mixing (e.g. DYER, 1997; MIRANDA et al. 2002). The river discharge induces stratification, and the tidal propagation produces mixing. The estuary is subjected to a micro-tidal regime, but its shallow waters result in high tidal range and mean depth ratio. This happens mainly during spring tides, making the system vertically homogenous due to the mixture produced by the tidal energy dissipation. However, even during spring tide, a vertically stratified structure is verified soon after the low slack tide, when the fluvial advection induces a stratification that lasts for approximately three hours. During the neap tide the stratification is observed throughout the tidal cycle, only with an alternating predominance of vertically saltier or less salty water. Saltier water dominates during flood tides while less salty water dominates during ebb tides.

In view of the time averaged conditions for two complete tidal cycles, the Camboriú estuary has been classified as partially mixed (type $2 b$ ) according to the stratification/circulation diagram proposed by Hansen and Rattray (1966, Fig. 6). The stratification/circulation diagram, despite its limitations, is still one of the most quantitative tools in classifying estuaries. The diagram is based on two non-dimensional parameters which provide information on the stratification level (stratification parameter) and on the importance of the gravitational circulation (circulation parameter) given by a simplified estuarine circulation model. The stratification parameter is obtained from the ratio of 


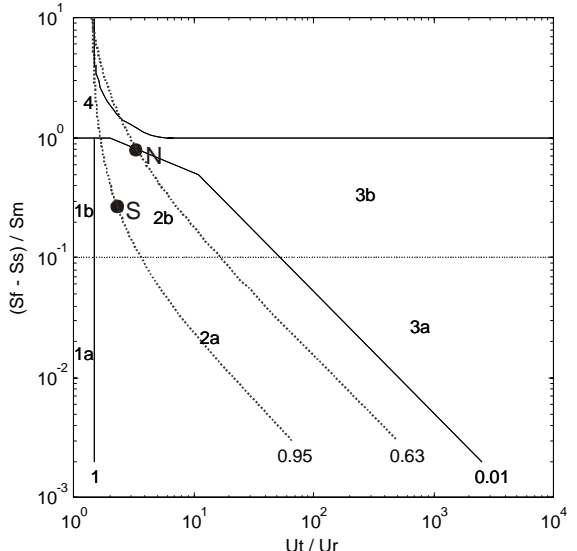

Fig. 6. Camboriú estuary classification for neap (N) and spring tide (S) according to the stratification/circulation diagram proposed by Hansen and Rattray (1966), also showing the parametric curve for the $v$ parameter (MIRANDA et al., 2002) for both conditions surveyed.

the difference between the bottom and surface salinity by the mean vertical salinity $\left(\mathrm{S}_{\mathrm{B}}-\mathrm{S}_{\mathrm{S}} / \bar{S}\right)$. The circulation parameter is given by the ratio of the residual tidal current on the surface and the contribution of the fluvial discharge to the residual velocity. The contribution of the fluvial discharge to the residual velocity is estimated by the ratio of the mean river discharge during the surveyed period and the cross-sectional area. However, if there is no information available on the river discharge, as is the case in this study, this term can be approximated by the mean residual velocity in the water column (MIRANDA et al., 2002). The stratification parameter is 0.87 and 0.28 for neap and spring tides, respectively, and the circulation parameter is 3.3 and 2.0 , in the same order. This result shows that the stratification during the neap tide is three times greater than that observed during the spring tide. The circulation parameter is also 1.5 times greater during neap tide. Once these parameters are defined, it is possible to define the parameter, which gives an indication of the relation between the advective and dispersive salt transport to the estuary. The parameter is obtained from the equation

$v=\frac{E^{-1}(210+252(C-1.5))+76(C-1.5)+50.7(C-1.5)^{2}}{E^{-1}(210+252(C-1.5))}$

derived by Miranda et al. (2002) from the relations presented by Hansen and Ratray (1966). $E$ and $C$ are the stratification and circulation parameters, respectively. The parameter varies between zero and one, with tending to zero meaning that the salt transport is dominated by advection and tending to one meaning that the salt transport is completely dispersive. The values are 0.63 and 0.95 for neap and spring tides, respectively. This means that during spring tide the stratified structure of the estuary is broken, inhibiting the gravitational circulation which would be the main mechanism of salt transport into the estuary. During neap tide, the lower tidal wave height is unable to break the stratification, allowing for the development of circulation in layers, with a dominance of dispersive transport, although the salt in the bottom layer is being transported into the estuary by advection.

\section{Suspended Sediment Transport}

The total suspended sediment transport, integrated for two tidal cycles for each survey, has been calculated for the bottom layer, up to $0.7 \mathrm{~m}$ above the bottom, and for the upper layer, from $0.7 \mathrm{~m}$ from the bottom to the surface, which varies with the water level during the tidal cycles. The total suspended sediment transport during the neap tide was directed seawards in the upper layer and landwards in the bottom layer. The transport in the bottom layer was of $72 \mathrm{~kg} \cdot \mathrm{m}^{-1}$, while in the upper layer it was of $-170 \mathrm{~kg} \cdot \mathrm{m}^{-1}$. In the light of the channel's width, the resulting respective transport during two tidal cycles is of 5,000 and $11,900 \mathrm{~kg}$ of suspended sediments in the bottom and upper layers. This gives a net seaward transport of $6,900 \mathrm{~kg}$. During the spring tide, the transport was seawards in both layers, resulting in a total of $32,400 \mathrm{~kg}$ for the two tidal cycles. Figure 7 summarizes the suspended sediment transport for each tide condition.

When a comparison is made with similar experiments conducted in the Itajaí-Açu estuary (SCHETTINI; CARVALHO, 1998), nearly $20 \mathrm{~km}$ north of the Camboriú estuary, both estuaries are seen to present agreement in the direction of transport during neap tide, although the transport was in the opposite direction during spring tide. In spite of the Itajaí-Açu receiving a much larger river runoff, the experiments of Schettini and Carvalho (1998) were conducted under conditions of very low river discharge, which allows a better comparison, with the tide being the main forcing in both cases. The main difference between the two estuaries is the water depth: $2 \mathrm{~m}$ in Camboriú, and $8 \mathrm{~m}$ in Itajaí-Açu, resulting in tidal amplitude/water depth ratios of $\sim 0.4$ and 0.1 , respectively. Neap tides produce gravitational circulation and bi-directional residual fluxes in both estuaries. The net exportation in the Camboriú estuary during the spring tide may be explained by tidal asymmetry, sediment resuspension, and tidal mixing breaking the stratification and minimizing the effects 
of gravitational circulation. On the other hand, the net importation in the Itajaí is explained by the role of gravitational circulation even during spring tide.

Figures $3 \mathrm{~F}$ and $4 \mathrm{~F}$ show the changes over time of the ratio between the near bottom SSC and its mean distribution in the water column $\left(C_{B} / \bar{C}\right)$. This ratio indicates the importance of the bottom sediments resuspension in controlling the water column SSC, since low values would indicate the dominance of advective processes (NICHOLS, 1984). The short lasting peaks of $C_{B} / \bar{C}$ coincide with flow velocity peaks for both ebb and flood tides. The instantaneous correlation between the near bottom SSC and its mean values in the water column has been high for both of the conditions surveyed, with $\mathrm{r}^{2}$ correlation coefficients at around 0.8 for both neap and spring tides (Fig. 8). These values indicate that the SSC in the water column are mainly related to the resuspension processes in the estuary. However, the low salinity values observed at low tide during both campaigns, and the high precipitation in the weeks that preceded the surveys, suggest that there is also a partial

A

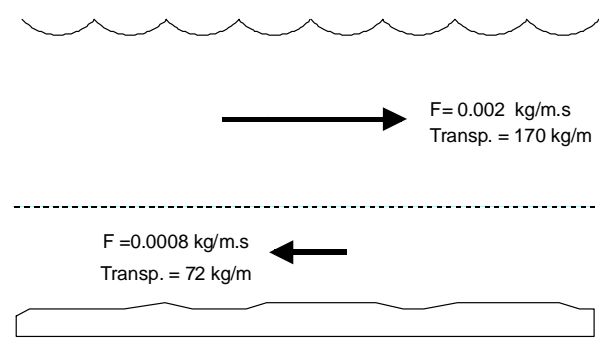

contribution of the fluvial advection of sediments. Drawing a simple analogy, considering that around $80 \%$ of the concentration variance is explained by resuspension, the fluvial contribution could be responsible for the other $20 \%$. However, the transport of suspended sediments through estuaries presents a much higher level of complexity (DYER, 1995). Given the importance of the tides in the salt transport in the estuary, tide will certainly influence the suspended sediments. Thus, the suspended sediments that arrive by river discharge are not delivered directly to the bay, but set off a cycle of deposition/erosion/transport within the estuary. Part of these sediments may be retained in the maximum turbidity zone due to the gravitational circulation (JAY; MUSIAK, 1994), while the other part will be exported by fluvial advection.

\section{Transport Mechanisms}

The salt transport was negative during neap and positive during spring tide, although both are

B

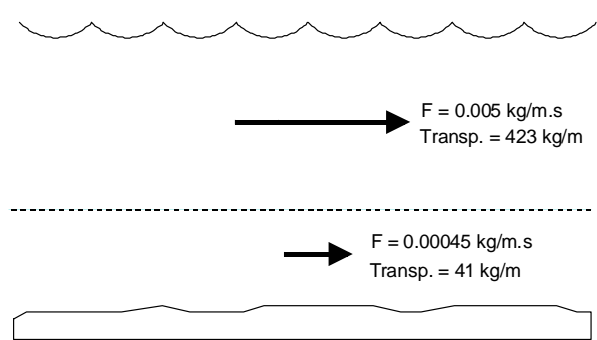

seaward

landward

Fig. 7. Diagram representing the fluxes $(\mathrm{F})$ and total suspended sediment transport (Transp.) for width unit at both layers: bottom and upper layer ( $\mathrm{A}$ - neap tide; $\mathrm{B}$ - spring tide).
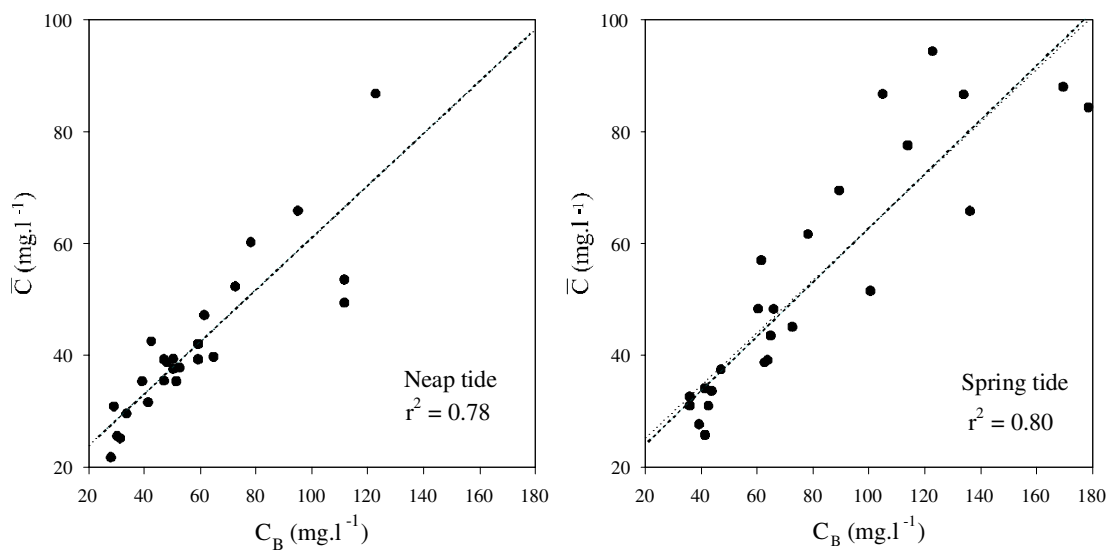

Fig. 8. Correlation between near bottom $\operatorname{SSC}\left(C_{B}\right)$ and mean water column distribution $(\bar{C})$ for neap and spring tide. 
similar in magnitude. This regime change is explained by changes in the drainage basin hydrology. There are no direct discharge measurements for the Camboriú river, however the daily precipitation values provide an indication of the hydrologic balance. Accumulated precipitation rates for seven and 14 days before the neap tide survey were of 38 and $134 \mathrm{~mm}$, respectively. For the spring tide survey, these values were 1.6 and $35 \mathrm{~mm}$. Given the reduced dimensions of the drainage basin $\left(200 \mathrm{~km}^{2}\right)$, the rain concentration time is of the order of hours. No precipitation occurred three days before the neap tide survey and nine days before the spring tide survey. The river discharge must have been similar for both surveys, with that of the neap period being probably a little higher, with a still descending hydrogram curve. The similar values obtained for the effect of river discharge advection for both experiments support this assumption. So the similarity of the hydrological regimes allows one to make a representative comparison for the other transport processes concerned.

The landward dispersive transport during neap tide was mainly due to gravitational circulation, followed by the tidal correlation. During spring tide, this transport is controlled mainly by the tidal correlation, followed by Stokes drift and gravitational circulation. Gravitational circulation is the geostrophic adjustment of water masses to a geopotential equilibrium, which in estuaries is balanced by the turbulent macro-diffusion generated by the tidal wave propagation maintaining the gradient at a sub-tidal frequency. During one synodical period, there will be more energy available for mixing at spring tides, increasing the baroclinic gradient. With the tidal regime changing to neap, the mixture capacity of the tides is reduced, allowing the development of gravitational circulation, and the consequent transport into the estuary.

The tide correlation term between the velocity and mean water column salinity during one or more tidal cycles tends to be small when the current regime is periodic and symmetrical, with a $90^{\circ}$ phase shift in relation to the salinity variations (MIRANDA et al., 2002). This term gains importance if there is a phase difference between slack water and extreme salinity values or in the case of time and intensity asymmetries in the current regime. The advective salt transport by this term during neap tide is small, being approximately only $1 / 3$ of the transport induced by gravitational circulation. On the other hand, during spring this term has the same importance as the seaward transport induced by river discharge. A possible explanation for this high value is the current asymmetry and the reduction of the river discharge during the field campaign.

The fourth term of importance in the salt transport into the estuary during spring tide is Stokes drift. Similar to the tidal correlation term, if the depth and current variations are periodic and symmetrical, with a $90^{\circ}$ phase shift, the tidal wave will be stationary and this term will be zero. If the phase shift is smaller, the tide behaves like a progressive wave, with mass transport during propagation. The advective suspended sediment transport terms for the neap tide experiment are the river discharge (downstream) and the tidal correlation (upstream). Differently from salinity, the suspended sediments are not a conservative scalar property since they undergo sedimentation and erosion processes. Even though the overall balance has been negative, with sediment exportation, the tidal effects carried sediments into the estuary during neap tide. As has been shown in the previous sections, the main sediment source for the water column on the crosssection studied was the bottom resuspension. However, the fine grained sediments under tide induced oscillatory conditions present a low resuspension threshold with even the weak flood tidal currents being able to resuspend the bottom sediments. The suspended sediment transport during the spring tide has been more complex and significant (being 20 times higher) than during the neap tide. Both river discharge and tidal correlation are higher and directed seawards. During neap the tidal correlation term presented the same order of magnitude, being slightly smaller than the river discharge term. During spring tide this term was the most important, being nearly twice as great as the river discharge term. One possible explanation for the inversion in the tidal correlation term is the effect of the broken stratified structure, with the resuspended sediments distributed in the water column being more effectively transported by the tidal currents. Counterbalancing these seaward directed terms, the Stokes drift and the gravitational circulation terms also had some relative importance, although secondary.

Comparing these findings once again with those from the Itajaí-Açu estuary, the advective transport terms during spring tide, obtained by applying the same procedures (MIRANDA et al., 2002), Schettini et al. (2006) found that the main salt and suspended sediment transport mechanisms were river discharge (seawards), and Stokes drift, tidal correlation and gravitational circulation (landwards). The most important term for the landward transport was the gravitational circulation, which in the Camboriú estuary plays a secondary role. The importance of tidal correlation in the seaward suspended sediment transport in the Camboriú estuary can be attributed to the ebb dominance of tidal currents and the erosion threshold, more effective during ebb tide. Both estuaries are ebb-dominant, although tidal erosion in the Itajaí-Açu will not induce water column homogeneous suspended sediment distribution, decreasing the tidal correlation term. 
Thus, the shallowness of the Camboriú and the ebb dominance explain the diversion of salt and suspended sediments transport by this term.

\section{Conclusions}

The Camboriú estuary is a shallow, partially mixed (type 2b) estuary. During neap tide it is continuously stratified but during spring tide the stratification is observed only at certain stages of the tidal cycle.

Suspended sediments exported by the estuary to the inner shelf during the periods studied were of $6,900 \mathrm{~kg}$ (or $3,200 \mathrm{~kg} / \mathrm{tidal}$ cycle) during neap tide and $32,400 \mathrm{~kg}$ (or $16,200 \mathrm{~kg} /$ tidal cycle) during spring tide, showing the importance of the tidal range in the sediment balance.

The main sediment source for the water column are the bottom sediments, periodically resuspended by the tidal currents. The field surveys were conducted during the rainy season, which also affected the suspended sediment volume and distribution.

The advective salt and suspended sediment transport was different between neap and spring tides, being more complex at spring tide. The river discharge term was important under both tidal regimes. The tidal correlation term was also important, being dominant in the suspended sediment transport during spring tide. The gravitational circulation and Stokes drift played a secondary role in the estuarine transport processes.

Since the field experiments, the Camboriú estuary inlet has been subjected to major morphological changes due to the construction of a jetty. Therefore, the information presented and discussed here provides important background information about the estuarine hydrodynamics and suspended sediment transport.

\section{ACKNOWLEDGEMENTS}

This work has been partially funded by the Balneário Camboriú municipality. The authors are sponsored by $\mathrm{CNPq}$ fellowships (Ref. $\mathrm{n}^{\circ}$ : ES: 308303/2006-7; CAFS: 306217/2007-4; AHFK: 307267/2006-7; EETJr: 300123/1995-7).

\section{REFERENCES}

BOON, J. D. Suspended solids transport in a salt marsh creek - an analysis of errors. In: KJERFVE, B. (Ed.)

Estuarine transport processes. Columbia: University of South Carolina Press, p. 147-159. 1977.

BOWDEN, K.'F. The mixing processes in a tidal estuary. J.

Air Wat. Pollut., v. 7, p. 343-356, 1963.
DYER, K. R. The salt balance in stratified estuaries. Estuar. coast. mar. Sci., v. 2, p. 273-281, 1974.

DYER, K.R. The balance of suspended sediment in the Gironde and Thames estuaries. In: KJERFVE, B. (Ed.). Estuarine transport processes. Columbia: University of South Carolina Press, 1977. p. 135-145.

DYER, K. R. Sediment transport processes in estuaries. In: PERILLO, G. M. E. (Ed.). Geomorphology and sedimentology of estuaries. New York: Elsevier, 1995. p.423-449.

DYER, K. R. Estuaries: a physical introduction. $2^{\text {nd }} \mathrm{ed}$. New York: John Wiley \& Sons, 1997. 195 p.

DYER, K. R.; GONG, W. K.; ONG, J. E. The cross sectional salt balance in a tropical estuary during a lunar tide and a discharge event. Estuar. coast. Shelf Sci., v. 34, p. 579591, 1992.

EISMA, D. Flocculation and de-flocculation of suspended matter in estuaries. Neth. J. Sea Res., v. 20, n. 1/3, p. 183-199, 1986.

FISHER, H. B. Mixing and dispersion in estuaries. Ann. Rev. Fluid Mech, v. 8, p. 107-133, 1976.

FÖRSTNER, U.; WITTMANN, G. T. W. Metal pollution in the aquatic environment. $2^{\text {nd }}$ ed. New York: Springer, 1983. $486 \mathrm{p}$.

FRANKLIN-SILVA, L.; SCHETTINI, C. A. F. Avaliação da dinâmica lateral e dos mecanismos de transporte no estuário do rio Camboriú. Notas Técn. Facimar, v. 7, p. 97-108, 2003.

HANSEN, D. V.; RATTRAY JR, M. New dimensions on estuarine classification. Limnol. Oceanogr., v. 11, p. 319-326, 1966

HUNKINS, K. Salt dispersion in the Hudson Estuary. J. Phys. Oceanogr., v. 11, p. 729-738, 1981.

JAY, D. A.; MUSIAK, J. D. Particle trapping in estuarine tidal flows. J. Geophys. Res., v. 99, 1984. (C10):2044520462. 1994.

KJERFVE, B. Circulations and salt flux in a well mixed estuary. In: VAN DE KREEK J. (Ed.). Physics of shallow estuaries and bays. Berlin: Springer-Verlag, 1986. p. 22-29.

MIRANDA, L. B.; CASTRO, B. M.; KJERFVE, B. Princípios de oceanografia física de estuários. São Paulo: Edusp, 2002. 414 p.

NICHOLS, M. M. Effects of Fine Sediment Resuspension in Estuaries. In: MEHTA, A. J. (Ed.). Estuarine cohesive sediment dynamics. Berlin/New York: Springer Verlag, 1984. p. 5-42. Lecture Notes on Coastal Estuarine Studies.

PEREIRA FILHO, J.; SCHETTINI, C. A. F.; RORIG, L. R.; SIEGLE, E. Intratidal variation and net transport of dissolved inorganic nutrients, POC and chlorophyll a in the Camboriú river estuary, Brazil. Estuar. coast. Shelf Sci., v. 53, p. 249-257, 2001.

PUGH, D.T. Tides, surges and mean sea-level. New York: John Wiley \& Sons, 1987. 472 p.

SCHETTINI, C. A. F. Caracterização física do estuário do rio Itajaí-Açu. Revta Bras. Recursos Hídricos, v. 7, n. 1, p. 123-142, 2002.

SCHETTINI, C. A. F.; CARVALHO, J. L. B. Suspended sediment balance in the estuary of Itajaí-Açu river during a low discharge period. An. Acad. Bras. Ciênc., v. 70, n. 2, p.325-334, 1998 
SCHETTINI, C. A. F.; RICKLEFS, K.; TRUCCOLO, E. C.; GOLBIG, V. Synoptic hydrography of a highly stratified estuary. Ocean Dynam., 2006. DOI 10.1007/s10236006-0066-1.

SCHETTINI, C. A. F.; CARVALHO, J. L. B.; JABOR, P. Comparative hydrology and suspended matter distribution of four estuaries in Santa Catarina State, Southern Brazil. Bahia Blanca, Proceedings of Workshop on Comparative Studies of Temperate Coast Estuaries, p29-32. 1996.

SHUBEL, J. R.; CARTER, H. H. The estuary as a filter for fine-grained suspended sediment. In: KENNEDY, V. (Ed.). The estuary as a filter. New York: Academic Press, 1984. p. 81-105.

(Manuscript received 23 October 2008; revised 16 February 2009; accepted 18 February 2009) 